\title{
The poor in the Epistle of James and the \\ Gospel of Thomas
}

\author{
Patrick J Hartin \\ Gonzaga University, \\ Spokane, Washington \\ United States of America
}

\begin{abstract}
This study explores similarities in the thought world of the Epistle of James and the Gospel of Thomas. Particular attention is devoted to the role that the 'poor' and 'poverty' play in both documents. For the Epistle of James it is 'the poor in the world that God has chosen to be rich in faith and heirs of the kingdom' (Ja 2:5). In a similar vein, in the Gospel of Thomas the kingdom is promised to those who have embraced the poverty of a radical life-style: 'Blessed are the poor, for yours is the kingdom of heaven' (GTh 54). This outlook betrays a basic ethos adopted toward the world. In both the Epistle of James and the Gospel of Thomas the relationship to the world ultimately determines one's relationship to the kingdom or to God. For the Epistle of James the very definition of religion demands that one keep 'oneself unstained from the world' (Ja 1:27) and that 'friendship with the world' is enmity with God (Ja 4:4). For the Gospel of Thomas the rejection of the world involves a radical ethos that embraces an intinerant life ('Be passersby' [GTh 42J), which includes a rejection of wealth (GTh 63). 'If you do not abstain from the world, you will not find the kingdom' (GTh 27). It is argued that the Gospel of Thomas and the Epistle of James reflect traditional sayings that endorse a similar ethos of radical discipleship.
\end{abstract}

\section{INTRODUCTION}

The theme of 'the poor' appears prominently in both the Hebrew and the early Christian writings. However, it functions differently in these various writings or traditions, providing a variety of emphases or interpretations. This study wishes to examine the theme of the 'poor' in two writings of early Christianity, namely the Epistle of James (in the New Testament canon) and the Gospel of Thomas (ultimately excluded from the canon of accepted books). These two writings (the Epistle of James and the Gospel of Thomas) are ones that are not usually associated together. Yet, each in its own way re- 
flects very similar traditions within early Christianity. They are both products of the developing sayings traditions ${ }^{1}$, that are also indebted to the age old wisdom heritage that reflects both a distinctive world view and strategy (Davies 1983). The connection of these two writings with both the sayings and the wisdom traditions has prompted this present study. This paper sets out to explore the theme of the 'poor' within these two writings with regard to three issues:

* The use and understanding of the notion of 'the poor' or 'poverty' in both writings.

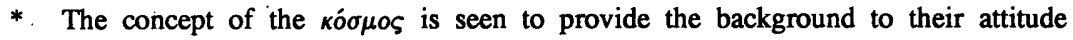
toward the poor.

* Finally, the question of the relationship between the thought world of these two writings will be addressed.

\section{ATTITUDE TO THE WORLD AS THE BACKGROUND TO 'THE POOR' IN THE EPISTLE OF JAMES}

\subsection{Friendship with the kó $\sigma \mu_{0}$ is enmity with God}

The attitude adopted toward the world explains the importance that the Epistle of James gives to the notion of 'the poor'. Here I wish to focus not so much on the use of the

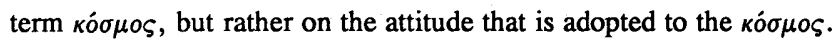

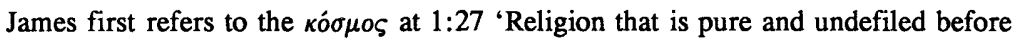
God, the Father, is this: to care for orphans and widows in their distress, and to keep oneself unstained by the world'. Dibelius (1976:121) argues that one's interpretation of this verse depends upon one's overall assessment of the Epistle of James and its relationship to Judaism: 'If one isolates the verse, then it can be interpreted very easily in Jewish terms'. However, taking the total context of the letter into account, it is difficult to read it solely in Jewish terms, as the letter itself does not betray any specific interest in purely cultic and ritualistic matters. Instead, it is best to see it in the context of a developing Christianity which sees the world in moral terms as that which is opposed to God and in this way exercises an influence for evil on the Christian. In this sense the world is viewed as hostile and harmful to the one who wants to exercise a true religion that demonstrates a relationship with God the Father. This passage spells out the very piety or spirituality of James, a piety that is rooted in a powerful mistrust of the world. The world leads one away from God. 
The same idea is conveyed even more strongly at 4:4 where James refers to the world on two occasions: 'Adulterers! Do you not know that friendship with the world is enmity with God? Therefore whoever wishes to be a friend of the world becomes an enemy of God'. The duality is very clear: a choice has to be made between allegiance to God or to the world. It is not possible to be friends with both. The opposition is evident in the context where the author accuses his readers of figurative adultery in the spirit of the prophetic accusations of the Old Testament against Israel. Just as an adulterer abandons the true love for the allure of a false one, so those who court the world are reminded that they have abandoned their true love, God, for the enticements of the world. In the Old Testament world such 'adultery' was seen as idolatry, as the abandonment of the true God for false gods. In James the enticement of the world also becomes idolatry for it takes one away from one's true allegiance to God. 'Here, as the context shows, adulteresses is figurative of idolatry, and the false god is the world' (Adamson 1989:170). In this sense it harks back to 1:27 where true religion was opposed to the contamination that comes from the world. Once again the world is that evil influence opposed to God.

A similar duality occurs in the Sayings Gospel Q: 'You cannot serve both God and wealth' (Lk 16:13; Mt 6:24). Here the opposition lies between God and wealth, whereas in James the opposition is between God and the world. Wealth is that aspect of the world that leads one away from God.

\subsection{Mistrust of 'the world' as the background to the 'poor' in James}

James's attitude of mistrust of the world runs throughout the epistle and provides a specific background to the way the poor are considered.

\subsubsection{Call to avoid discrimination on the basis of wealth (Ja 2:1-13)}

In this passage James brings together the notions of 'world' and 'the poor': 'Listen, my beloved brothers and sisters. Has not God chosen the poor in the world to be rich in faith, and to be heirs of the kingdom that he has promised to those who love him?' (2:5). At first sight this term кó $\mu \circ \varsigma$ appears to refer simply to 'humanity'. However, this is a humanity that makes a judgment independently of the guiding force of faith. The values and judgments that 'the world' makes are values and judgments different from and opposed to the values and judgments made by someone who is influenced by faith.

This passage marks the beginning of the main body of the epistle (2:1-13). It introduces a consideration of a theme that was announced at the beginning of the epistle, namely the rich and the poor (1:9-11). Elsewhere, I have argued (Hartin 1991:30) that 
chapter one provides two introductory sections (1:2-11; and 1:12-27) which present the basic themes that are taken up in the body of the epistle, starting with the section 2:113. This theme of the rich and the poor returns again at the end of the epistle (5:1-6). Structurally, then, the theme of the rich and poor forms an inclusion with regard to the body of the epistle: it contains the opening and closing statements of the body of the epistle.

The announcement not to show partiality (2:1) dominates what follows. In effect James argues that true faith excludes the making of social distinctions - something so common among the values of the world (Davids 1982:105). James illustrates the picture with an example whereby the community discriminates against the poor in favor of the rich. The usual assumption is that the assembly ( $\sigma v \nu \alpha \gamma \omega \gamma \eta$ ) referred to here is the worshipping community and they are the ones who are discriminating against the poor. However, a number of more recent studies has argued for the view that James has a judicial community in mind. Most noticeably it was Ward (1969:87-97) who demonstrated that the contrasts of the rich/poor, fine clothes/rags, were typical of Jewish rabbinic discussions. Just as the Jewish synagogue had a judicial function, so one can see this same function being adopted by the Christian community. This means that the assembly that James has in mind is a judicial assembly of the church and those who come in are in fact strangers to the proceedings (Davids 1982:109-110; and Patterson 1993:181-182). The content of this passage (2:1-8) supports the context of a judicial court: the charges brought against the rich condemn their actions against the poor in the legal sphere. What is important here is the condemnation of the way in which the rich discriminate against the poor person.

James 2:1-7 indicates a shift of attitude toward the poor within the community. He issues a call to remember God's actions and God's particular concern for the poor: 'Has not God chosen the poor in the world to be rich in faith and heirs of the kingdom that he has promised to those who love him'? (2:5). This concern of God for the poor is a major Old Testament theme and consideration (for example, Dt 16:3; and 26:7). In the intertestamental period this theme also dominates: 'It is not right to despise one who is intelligent but poor, and it is not proper to honor one who is sinful' (Sir 10:23; see also, for example, 1QpHab 12:3, 6, 10).

While the call to remember refers to the actions of God in the Old Testament, it also reflects the teaching of Jesus with regard to the poor found in the Sermon on the Mount/Plain, to which the Gospel of Thomas (54) also bears witness. The original Q beatitude read: 'Blessed are the poor, because theirs is the kingdom of God' ( $\mu \alpha \kappa \alpha$ oro

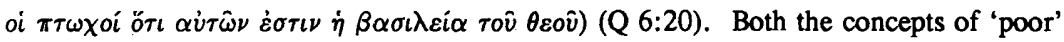
and 'kingdom' appear in James, $Q$, and Thomas. James has specified the notion of the 
poor as 'poor in regard to the world' ( $\pi \tau \omega x \circ \grave{\varsigma} \varsigma \hat{\varphi} \kappa \sigma \sigma \mu \varphi)$ ). It is only Matthew who has qualified the notion of poor by referring to it as 'poor in spirit' (oi $\pi \tau \omega x o \grave{\tau} \tau \hat{\varphi}$ $\pi \nu \varepsilon \dot{v} \mu \alpha \tau)$. In this development James lies closer to the heart of the $Q$ beatitude for he has still preserved the reference to material poverty. For James the materially poor person is the one suffering discrimination (Davids 1982:112). James has also preserved a close connection between the poor and the kingdom; the poor in regard to the world become rich in regard to faith and heirs of the kingdom. The beatitudes make a similar connection. For James both the teaching of the Old Testament as well as the teaching of Jesus are a reminder to the audience that God's choice of the poor is something that ultimately brings them to the inheritance of the kingdom.

James further reminds his readers that in effect the rich have been responsible for many of the hardships that the community has endured: they oppress the members of the community, they drag them into court, they even blaspheme the name of Jesus (2:67). James tells his readers that their actions of discrimination not only dishonour the poor, but they do something worse: they side with those who are persecuting the poor (Davids 1982:112). In this instance the 'rich' are not the actual members of the community; James makes the contrast between you ( $\dot{v} \mu \hat{\omega} \nu \ldots i \hat{v} \mu \hat{\alpha} \varsigma)$ who are the heirs ( $\pi \tau \omega \chi 0$ ovs) of the kingdom and they (the rich) who drag you into court. The rich are a group outside the community, but the community is moving to seek their support at the expense of their traditional practice of supporting the poor (Davids 1982:112). Patterson (1993:182), on the other hand, sees the rich as a group within the church. However, I think the contrast that is drawn between 'you' and 'they' does indicate that the rich are the 'they' and are outside the community. Nevertheless, I do not think that this militates against Patterson's basic thesis (1993:182) that the wealthy are trying to gain the attention of the community. One could go further and say that the rich are beginning to seek entry into the church: this is evidenced by the rich person in the story who comes into the assembly: it certainly shows someone who wants to gain entrance. Again the enthusiasm of the members of the community is noted: they give him a great welcome hoping in this way to bring him into their community. This reinforces the picture of a community that is shifting its focus of interest from the poor to the rich. Not only does the community curry favour with the rich, but they also do this at the expense of the poor. As Bammel (1971:911) says: 'As far as the situation in James is concerned one can merely say that the rich were beginning to seek entry into the church and the poor had already come to be esteemed less highly'.

James' community demonstrates that it is situated at the crossroads: their concern changes from traditional hospitality to the poor to that of establishing friendships and bonds with the rich and influential ${ }^{2}$. 


\subsubsection{Arrogance of the rich (Ja 4:13-17 and 5:1-6)}

With these two pericopes the body of the epistle comes to a conclusion. James returns to the theme of the relationship of the rich-poor. Two distinct groups of rich are envisaged here: the merchant class (4:13-17) and the landowners (5:1-6). Once again the background of the world provides the specific teaching about riches and poverty.

James 4:13-17 envisages a merchant group which is leading its life independently of the trust and commitment that they should demonstrate in God. The previous pericope had made the point that 'friendship with the world is enmity with God' (4:4). This pericope is a concrete illustration of this opposition between the world and God. The lure of riches entices them away from allegiance to God's will. But, there is more to the condemnation of the rich than a refusal to rely upon God's will in all they do. They also fail to act in the way in which they should: 'Anyone, then, who knows the right thing to do and fails to do it commits sin'. (4:17). What is the right thing that they know they should do? They are hording their wealth instead of sharing it with the poor (Davids 1982:174; Laws 1980:193). Against this is the allure and attraction of the world that leads them to forget their basic responsibility to have a concern for the poor and to share one's wealth with the poor.

James 5:1-6 speaks much in the line of the prophets of the Old Testament. He addresses the wealthy landowners outside the community. The wealth they have amassed is about to disintegrate. They are charged with gaining their wealth at the expense of the poor. Even worse: they have held back wages from the harvesters. This is a very serious allegation for the labourer and his family depended upon the daily wage that they received. Failure to receive such a wage would place them in a dire situation. For this reason the Old Testament enacted numerous laws requiring a just wage to be paid (Lv 19:13; Dt 24:14-15; Job 7:1-2; 24:10; 31:13, 38-40; Jr 22:13; Ml 3:5; Sir $7: 20 ; 31: 4 ; 34: 21 \mathrm{ff} ;$ Tob $4: 14)$. This is the epitome of injustice, an injustice performed against the poor.

By concluding the body of the epistle with this passage James reminds the community once again of the evils perpetrated by the rich. Remember well what the rich are doing! They are extorting wages from the poor and ultimately God will intervene to punish them: they are being prepared for 'a day of slaughter'. It is a final appeal to the community not to shift the focus. He appeals to them not to forget the poor, the traditional focus of their concern, and to distance themselves from the evil intentions and actions of the rich. 


\section{3. 'THE WORLD' AS CONTEXT FOR 'THE POOR' IN THE GOSPEL OF THOMAS}

Since the discovery of the Gospel of Thomas many areas have dominated its study. The major question undoubtedly has been its connection to Gnosticism (Fallon \& Cameron 1988:4195-4251) ${ }^{3}$. Within this consideration the relationship of the Gospel of Thomas to the Synoptic Gospels has also received much attention ${ }^{4}$. However, an impasse has now been encountered: positions have become polarized with little hope of moving forward along a path that is acceptable to all parties. This presentation aims at shifting the discussion by examining the Gospel of Thomas in conjunction with another (and seldom referred to) thought world of early Christianity, namely the Epistle of James. In this consideration I simply wish to limit myself to the examination of two similar concepts occurring in both writings, namely the 'cosmos' and 'the poor'.

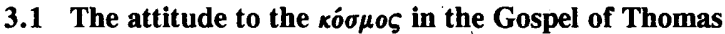

Many of the distinctive features of the Gnostic understanding of the world are not clearly evident in the Gospel of Thomas: there is no reference to the multiplicity of the aeons, the fall of Sophia, or the creation of the material world, et cetera (Haenchen 1973:207). However, as with the consideration of the Epistle of James, my interest lies not with an examination of the usage of the term 'kosmos' in the Gospel of Thomas, but rather with the attitude that the Thomas Christians are encouraged to adopt toward the world (Marjanen 1994:11).

\subsubsection{The world as background to the activity of Jesus and the Thomas Christians}

Jesus refers to his mission as casting fire upon the world: 'I have cast fire upon the world, and behold, I am guarding it until it blazes' (GTh 10$)^{5}$. What exactly Jesus intends by this remark is unclear. Later when he again refers to his mission with a further reference to 'fire', more clarity does emerge: 'Perhaps people think that I have come to cast peace upon the world. They do not know that I have come to cast conflicts upon the earth: fire, sword, war' (GTh 16). Here, Jesus presents his task as bringing the world to make a decision with regard to him. This task causes division in that some choose for him, others choose against him. These choices produce those conflicts that result in 'fire, sword, war'. The world's response to Jesus is characterized negatively, as one of drunkenness and blindness. 'I took my stand in the midst of the world, and in flesh I appeared to them. I found them all drunk, and I did not find any of them thirsty. My soul ached for the children of humanity, because they are blind in their hearts and do not see, for they came into the world empty, and they also seek to depart from the world empty' (GTh 28). 
Like Jesus, the Thomas Christians also exercise a function with regard to the world. In response to their request to show them where they can find him, Jesus tells them to look within themselves, for they are people of light, and this light should illuminate themselves as well as others: 'There is light within a person of light, and it shines on the whole world. If it does not shine it is dark' (GTh 24). The world is the arena where the Thomas Christians work and they are to let their light shine upon it. Their activity, like that of Jesus in the Gospel of Thomas (Logion 28), is to let their light overcome the blindness of the world. Their attitude to the world induces them to exercise a missionary thrust in order to let their light illuminate the darkness of the world. The parable of lighting the lamp continues this thought: 'For no one lights a lamp and puts it under a basket, nor does one put it in a hidden place. Rather, one puts it on a stand so that all who come and go will see its light' (GTh 33).

One of the major thrusts of the Gospel of Thomas is the wandering radical spirit that directs the life of the Thomas Christians. Their missionary zeal is spurred on by Jesus' instruction to let their light shine on the world. 'When you go into any country and walk from place to place, when the people receive you, eat what they serve you and heal the sick among them' (GTh 14).

\subsubsection{The world is a dangerous place: one is to protect oneself from the world} A distinct separation exists between the Thomas Christian and the world. By nature the two are different. The world is compared to a dead body (a corpse), while the disciple is a living being. 'Whoever has come to know the world has discovered a carcass, and whoever has discovered a carcass, of that person the world is not worthy' (GTh 56). Not only are the Thomas Christians separate from the world, but the world is also not worthy of them. The same idea occurs on two further occasions: 'Whoever has come to know the world has discovered the body, and whoever has discovered the body, of that person the world is not worthy' (GTh 80). The only real difference between Logion 56 and Logion 80 is that Logion 56 refers to 'a carcass', while Logion 80 speaks of a 'body'. According to Meyer (1992:91): 'Some scholars have suggested that "carcass" and "body" could both derive from the Aramaic word pigra, "corpse, body"'.

This same contrast between the world and the life of the disciple is continued in Gospel of Thomas 111: 'Whoever has found oneself, of that person the world is not worthy'? (GTh 111). This phrase 'of that person the world is not worthy' occurs on three occasions (Logia 56, 80 and 111). It is in fact a saying found in Jewish literature as a way of praising someone (Meyer 1992:108). As a saying it is reinforcing the theology of Thomas that there is a fundamental difference between the world and the disciple: the life that the disciples possess separate them from the world. 
The world poses a great threat to the Thomas Christians. In the context of two parables (GTh 21) they are warned against the world. In the first of the parables they are compared to children. The image of a child occurs in the New Testament traditions to indicate the true followers of Jesus. "Truly I tell you, whoever does not receive the kingdom of God as a little child will never enter it'. And he took them up in his arms, laid his hands on them, and blessed them" (Mark 10:15-16; see also Mt 19:13-15 and Lk 18:15-17). In this parable (GTh 21) the children are living in a field that is not theirs. The field is their flesh which they shed when they are liberated from their bodies: 'They take off their clothes in their presence in order to give it back to them, and they return their field to them'. In the second of the parables the Thomas Christians are urged to remain alert. Like a householder who does not know when the thief is going to break into his house, they do not know when the world will attack them. 'As for you, then, be on guard against the world. Gird yourselves with great strength, lest the robbers find a way to get to you, for the trouble you expect will come' (GTh 21). Of one thing they can be sure: attacks and dangers will come. This calls for constant vigifance against the ever certain dangers from the world.

To protect themselves the Thomas Christians are urged 'to fast from the world'. 'If you do not fast from the world, you will not find the kingdom. If you do not keep the sabbath, you will not see the Father' (GTh 27). 'Fasting from the world' means that one abstains from the material things of the world. Gärtner (1961:239) explains the concept 'to fast from the world' in this way: "To 'fast from the world' is an expression which is not found in the New Testament but which in the subsequent history of the Church became the normal expression for asceticism". The ascetical way of life finds its roots in this admonition. The attitude to the world ultimately dictates the Thomas Christian's lifestyle. Because the world presents a danger, the Thomas Christians are to protect themselves from the world 'by fasting', by adopting a rigorous ascetical way of life. Clement of Alexandria adopts the term 'fasting from the world' in a sexual abstinence context: "But 'those who have made themselves eunuchs' free from every sin - 'for the kingdom of heaven's sake', in fasting from worldliness, find blessing" (Ferguson 1991:318). Marjanen (1994:17) supports this understanding: 'In the context of the Gospel of Thomas, it seems at least obvious that Thomas Christians were demanded to abstain from sexual intercourse and probably from marriage as well. According to Logion 27, a failure in that respect prevented him/her from entering the kingdom, that is from receiving salvation'.

Among other things abstinence from the world also implies the renunciation of all wealth: 'Let one who has found the world, and has become wealthy, renounce the world' (GTh 110). And again: 'Let one who has become wealthy reign, and let one 
who has power renounce (it)' (GTh 81). In particular the renunciation of the world is asked of those who are wealthy because material possessions are a sign of one's allegiance to and influence from the world.

\subsection{Rejection of 'the world' as the background for 'the poor' in the Gospel of Thomas}

The Gospel of Thomas demands a specific attitude to the world. In effect this attitude will determine the Thomas Christian's style of life. They struggle with the world as they try to be faithful to their understanding of Jesus' words. Patterson (1990:102) shows how this struggle presumes a violent context: 'Jesus said: "The kingdom of the Father is like a person who wanted to put someone powerful to death. He drew his sword at home and thrust it into the wall to find out whether his hand would go in. Then he killed the powerful one"' (GTh 98). An examination of the Gospel of Thomas will illustrate what consequences this attitude has.

\subsubsection{Withdrawal from the world}

One of the most discussed passages of the Gospel of Thomas is Logion 42: 'Jesus said: "Be passersby". While this passage has been interpreted in a variety of different ways, particularly by those wishing to give it a Gnostic colour (Fieger 1991:139), I think that the simplest understanding is to read it as a call to embrace a wandering lifestyle precisely because the world as such is a threat (Patterson 1993:128-131). This is supported by other sayings in the Gospel of Thomas which endorse the wandering life style: 'When you go into any country and walk from place to place, when the people receive you, eat what they serve you and heal the sick among them' (GTh 14.4). They also have no fixed abode: 'Jesus said: "Foxes have their dens and birds have their nests, but the child of humankind has no place to lay his head and rest"' (GTh 86). As Patterson observes here, the literal translation of 'the child of humanity' is 'son of man', but what is intended is not a reference to a title for Jesus but simply to an Aramaic expression for a human person. So it is a term that has a general reference to all humanity and not a specific one restricted to Jesus alone. In this context Jesus is referring, not to himself, but all humanity who should embrace this wandering lifestyle.

This wandering lifestyle gives impetus to other radical behaviour. All this flows from the basic understanding of the world as dangerous and evil, to be avoided at all costs. There is no question of any attempt being made to convert or to transform the world. That is not possible. The only approach is to shun the world and to escape from it: to adopt the radical lifestyle of one who does not enjoy a fixed abode. 


\subsubsection{Embracing poverty}

When the Gospel of Thomas uses the terms 'poor and poverty', it does so in two ways:

(a) In a metaphorical sense: 'Jesus said: "If the flesh came into being because of spirit, it is a marvel, but if spirit came into being because of the body, it is a marvel of marvels. Yet I marvel at how this great wealth has come to dwell in this poverty"' (GTh 29). In this sense the spirit is the treasure, the wealth, which comes to dwell in the body (something to be shunned) which is referred to as poverty.

(b) In a literal sense: Poverty, or the poor are literally to be embraced by the disciple. For example: 'Jesus said: "Blessed are the poor, for yours is the kingdom of heaven"'(GTh 54). As with the Gospel of Luke it is the material poor who are invoked as blessed. They are the ones whom the disciples must seek to emulate.

For the Gospel of Thomas poverty is a consequence of the voluntary rejection of those values that look to the world as the source of every effort and activity. The same beatitude that begins the $\mathrm{Q}$ beatitudes is found in the Gospel of Thomas in virtually the same form: 'Blessed are the poor, for yours is the kingdom of heaven'(GTh 54). The material understanding of poverty is evident both here in the Gospel of Thomas and in $Q$. Poverty has not been spiritualized as happened in the development of the beatitude in the Gospel of Matthew.

At the heart of this lifestyle lies the clear option to embrace this way of life: they are poor by design, not by force of circumstances. The life of poverty has been voluntarily embraced: "Jesus said: "Let one who has found the world, and has become wealthy, renounce the world"'(GTh 110).

A sharp criticism of the wealthy emerges from the series of parables in the Gospel of Thomas 63-65. In the parable in Logion 63 the rich person invests his money in the things of this world: that night he dies. This shows the fleeting nature of investing in wealth. Far rather should one place one's values in what lasts. In the parable found in Logion 64 the invited guests all excuse themselves from participating in the dinner on grounds of business concerns: some merchants are collecting money; some are purchasing a house; others are preparing a wedding dinner; while yet others are arranging the purchase of a new estate. Ultimately the parable concludes with the saying of Jesus: 'Buyers and merchants will not enter the places of my Father'. They are to be excluded because their concerns lie with the affairs of this world. By willfully renouncing the affairs of this world, one embraces a life of poverty which brings one closer to the kingdom of the Father. 
The third parable in this series continues the repudiation of business enterprises. The possession of property (in this case a vineyard) leads to a situation involving rebellious tenants. The owner's vineyard is in jeopardy; but worst of all the tenants put the owner's son to death. The greed emanating from the world is responsible for the death of the heir of the vineyard. By endorsing the values of the world one ultimately embarks upon a path that leads to destruction.

The itinerant preachers who hand on these sayings overturn the accepted values of the world. They are proud of these new values because they have voluntarily chosen them, voluntarily chosen this life of poverty. The results of this choice also have positive advantages: their hunger, for example, is an opportunity to receive the blessing of God on which they now rely for their sustenance: 'Blessed are they who are hungry, that the stomach of the one in want may be filled'(GTh 69).

The wealthy are also challenged to a voluntary renunciation of the world:

* The Gospel of Thomas challenges those who use their wealth to buy power to reverse their values: happiness will come if they use their freedom to renounce their power: 'Jesus said, "Let one who has become wealthy reign, and let one who has power renounce (it)"'(GTh 81).

* In like manner the Gospel of Thomas (Logion 76) shows how a merchant sells everything he has in order to acquire a pearl, that one most precious treasure. This comparison endorses the call to seek that which is most valuable and enduring: 'So also with you, seek his $(=$ the) treasure that is unfailing, that is abiding, where no moth comes to consume and no worm destroys'. In attaining that most precious of all treasures, one has to give up everything else. In this sense poverty is embraced in order to attain the most valuable thing of all.

* The parable of the fisherman in the Gospel of Thomas (Logion 8) is identical in scope: the wise fisherman throws away all the fish he has caught in order to preserve and keep the large one. It is necessary to give up everything else for what one prizes above all.

* The parable of the shepherd (GTh 107) endorses the same perspective: the shepherd forsakes the entire flock to seek out the stray sheep which he prized most of all. To find it he willingly sacrificed all the other sheep.

These parables serve as an illustration for Thomas' audience to place their energies in seeking what is most precious and to give up voluntarily everything else in order to ac- 
quire it. The best way to use wealth, money, is in fact to give it away: 'Jesus said, "If you have money, do not lend it at interest. Rather, give it to someone from whom you will not get it back"' (GTh 95).

Failure to embrace this radical reversal of values leads ultimately to an evil existence: one has fallen into the snares of the world. In the parable of the hidden treasure (GTh 109), the buyer who discovered the treasure uses it wrongly in order to lend out money at high interest: he breaks one of the most basic of Israelite laws, that of usury. The new found wealth led the buyer into evil and he succumbed.

The Gospel of Thomas considers money, wealth, possessions as worthless: it endorses a total reversal of values. These sayings have as their goal the justification of the lifestyle that the wandering preachers have embraced. The only authentic way of life rests in the rejection of the world and the adoption of a life of poverty: 'Jesus said, "Let one who has found the world, and has become wealthy, renounce the world" (GTh 110).

\section{THE GOSPEL OF THOMAS AND THE EPISTLE OF JAMES BETRAY A SIMILAR ETHOS OF RADICAL DISCIPLESHIP}

This examination has endeavoured to show that these two documents emerge from similar thought worlds which hand on the sayings traditions in their own inimitable way ${ }^{6}$. At the root of their similarities lies the wisdom dimension and sayings traditions that produce an attitude to the world that embraces a similar radical ethos. While the literary form of each document does differ, they both depend in large measure upon wisdom material. James is above all a paraenetical writing which aims at giving advice and direction to its readers. Thomas on the other hand belongs to the trajectory of sayings collections. However, both James and Thomas depend upon wisdom sayings traditions for what they communicate. James transposed these sayings more than Thomas did, yet behind the paraenetic teaching of James one can clearly see the form of a saying that provided the impetus for the teaching itself (Hartin 1991:140-198) ${ }^{7}$.

Using sayings that have come down to them in different ways and being heirs to a common wisdom heritage, both the Gospel of Thomas and the Epistle of James demonstrate a basic ethos adopted to the world that gives direction to the way of life of the members of their respective communities. In both the relationship to the world ultimately determines the relationship to the kingdom or to God. What is most noteworthy is the attitude of mistrust of the world that dominates both traditions. For the Gospel of Thomas the rejection of the world involves a radical ethos that embraces an itinerant life ('Be passersby' [GTh 42]), which includes a rejection of wealth (GTh 63) and a total renunciation of the world: 'If you do not fast from the world, you will not find 
the kingdom' (GTh 27), together with it family ties and traditional piety. For the Epistle of James the very definition of religion demands that one keep 'oneself unstained by the world' ( $\mathrm{Ja} 1: 27$ ) and that 'friendship with the world is enmity with God' (Ja 4:4). James likewise is highly critical of wealth and the evils that the rich have perpetrated against the poor, in particular against the members of his community. Business enterprises are frowned upon because they lead one away from living the correct type of life.

This attitude to the world has given direction to the notion of the poor as the true members of the community in both instances. Poverty entails a radical lifestyle which shuns the world. In the Gospel of Thomas the kingdom is promised to those who have embraced the poverty of this radical life-style. 'Blessed are the poor, for yours is the kingdom of heaven' (GTh 54). In a similar vein for the Epistle of James it is 'the poor in the world that God has chosen to be rich in faith and heirs of the kingdom' (Ja 2:5). It is clear that both James and Thomas endorse a material poverty (not a spiritual one)'.

However, where James does differ from Thomas is within his community where a shift of attitude takes place with regard to the poor: something about which the author is concerned. Instead of being a community identified with the poor, as has been the case from the beginning, they now 'have dishonoured the poor' (Ja 2:6) by their actions of courting the rich. While for Thomas the focus is clearly upon this itinerant group of preachers who are poor, in James the community is more settled and with it the allure of wealth and the rich are beginning to draw the allegiance of the members away from their traditional acceptance of the poor.

The attitude of both the Epistle of James and the Gospel of Thomas to merchants and businessmen is also very similar. The parables of the Gospel of Thomas (GTh 6365) show clearly how the merchants have made a choice for the world against God: 'Buyers and merchants will not enter the places of my father' (GTh 64). James speaks out in strong prophetic mode against the merchants and the rich for making their plans independently of God (Ja 4:13-17). In addition they are responsible for many of the hardships that the poor members of the community have endured: they have kept back the wages of the daily labourers which hurts those who depend upon each day's wage to support them (Ja 5:4).

The shift in attitudes toward poverty within the community of James shows that we are still at an early stage in the development of early Christianity. However, it is a stage where the previous concern for the poor is now fading. The epistle is a call to return to that concern and hospitality that was evident before. Now a transition is occurring. 
The Gospel of Thomas and the Epistle of James both rest upon those early traditions that endorse similar attitudes toward the world that impact upon a radical lifestyle of poverty and mistrust of the world. They share this common ethos. The symbolic language of 'the world' and 'the poor' functions in a similar way in the Gospel of Thomas and the Epistle of James. The purpose of symbolic language is to help one make sense of reality - to make sense of the chaos around one. The Gospel of Thomas and the Epistle of James do so in remarkably similar ways.

\section{End Notes}

1 Among the clearest illustrations of the sayings traditions are the Sayings Gospel Q, the parable collection of Mark 4, the Epistle of James, the first six chapters of the Didache and the Gospel of Thomas (Patterson 1990:93).

2 I think that Patterson's observation (1993:182-183) in this connection is worth noting. Patterson suggests that one should see this group of poor in James as including the wandering mendicant missionaries who had traditionally been granted hospitality by the community. He finds support for this picture of a group of wandering mendicants approaching James' community from the next passage (2:14-26). Here fellow Christians come seeking food and clothing and the members of the community say to them: 'Go in peace; keep warm and eat your fill' (2:15). In other words 'you' send them on their way without helping them. Patterson sees this as an issue of the refusal of hospitality to those who are travelling. This is an interesting insight and one that needs further examination.

3 Basically three approaches have been adopted:

* The final form is Gnostic. For example: McL Wilson 1960; Haenchen 1961; Schrage 1964; Rudolph 1977; Fieger, 1991.

* The final form demonstrates at the very least gnosticizing tendencies. For example: Koester, 1989, 38-45; Patterson 1993.

* No indication of an awareness of Gnosticism. For example: Davies 1983; Layton 1987.

4 In large measure two opposing solutions have been proposed by the scholarly community: namely, the view that argues that Thomas is dependent upon the Synoptic Gospels (European scholars have largely endorsed this approach); and the view that argues that Thomas represents a tradition altogether independent from the synoptics (North American scholarship has favoured this perspective, particularly the centres of Claremont and Harvard).

5 The quotations from the Gospel of Thomas are from the translation of Meyer (1990:129-155). 
6 The authority of James is important for both documents. In the Gospel of Thomas James is referred to at Logion 12: 'No matter where you are, you are to go to James the Just, for whose sake heaven and earth came into being'. The Epistle invokes the authority of James at the outset: 'James, a servant of God and of the Lord Jesus Christ'. While Thomas identifies James as 'the Just' according to the tradition about James, the Epistle of James does not. The epistle simply identifies James as 'a servant'. What is significant about the usage of the epistle is that while many people with the name of James were evident in the Christian communities, the author finds it unnecessary to be more specific. The James referred to here is undoubtedly the most influential James in the New Testament period: James, the Just, the brother of the Lord. Both documents invoke the authority of this figure for their traditions. Consequently, they must come from communities for whom the authority of James was an important reality.

7 The probable location for the emergence of the Epistle of James and the Gospel of Thomas is the same: Syria. Apart from the previously discussed importance given to James which would argue for a Syrian provenance, James must originate from a place where the Synoptic traditions were alive as is seen from the numerous reflections of the Synoptic sayings traditions evident in the Epistle. In addition both the Jewish and Hellenistic characteristics of the epistle would also find a Syrian location most congenial.

\section{Works Consulted}

Adamson, J 1989. The Epistle of James. (The New International Commentary on the New Testament.) Grand Rapids: Eerdmans.

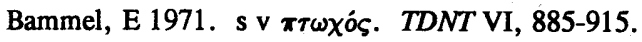

Davids, P H 1982. The Epistle of James: A Commentary on the Greek Text. Grand Rapids: Eerdmans.

Davies, S L 1983. The Gospel of Thomas and Christian Wisdom. New York: Seabury.

Dibelius, M 1976. James: A commentary on the Epistle of James, revised by $\mathrm{H}$ Greeven, translated by M A Williams. Philadelphia: Fortress.

Fallon, F T \& Cameron, R 1988. The Gospel of Thomas: Forschungsbericht and analysis. $A N R W 25 / 6,4195-4251$.

Fieger, M 1991. Das Thomasevangelium: Einleitung, Kommentar und Systematik. Münster: Aschendorff.

Ferguson, J 1991. Clement of Alexandria: Stromateis, Books One to Three. Washington: Catholic University of America.

Gärtner, B 1961. The Theology of the Gospel according to Thomas. New York: Harper.

Hartin, P J 1991. James and the ' $Q$ ' Sayings of Jesus. Sheffield: Sheffield University. Haenchen, E 1961. Die Botschaft des Thomasevangeliums. Berlin: Töpelmann.

1973. Die Anthropologie des Thomas-Evangeliums, in Betz H D \& Schottroff, L (eds), Neues Testament und christliche Existenz: Festschrift für Herbert Braun. Tübingen: JCB Mohr (Paul Siebeck). 
Kloppenborg, J S 1988. Q Parallels. Sonoma: Polebridge.

Koester, H 1989. The Gospel according to Thomas: Introduction, in Layton, B (ed), Nag Hammadi Codex II,2-7, vol 1, 38-45. Leiden: Brill.

Layton, B 1987. The Gnostic Scriptures. Garden City: Doubleday.

Laws, S 1980. A Commentary on the Epistle of James. London: Black.

Marjanen, A 1994. Cosmos in the Gospel of Thomas, a paper presented to the meeting of the Thomas Consultation of the Society of Biblical Literature.

McL Wilson, R 1960. Studies in the Gospel of Thomas. London: Mowbray.

Meyer, M W 1990. The Gospel of Thomas: Text and Translation, in Kloppenborg, J S, Meyer, M W, Patterson, S J, \& Steinhauser, MG (eds), Q-Thomas Reader. Sonoma: Polebridge.

Meyer, M W 1992. The Gospel of Thomas. San Francisco: Harper.

Patterson, S J 1990. The Gospel of Thomas: Introduction, in Kloppenborg, J S, Meyer, M W, Patterson, S J, \& Steinhauser, M G (eds), Q-Thomas Reader. Sonoma: Polebridge.

Patterson, S J 1993. The Gospel of Thomas and Jesus. Sonoma: Polebridge.

Rudolph, K 1977. Die Gnosis: Wesen und Geschichte einer spätantiken Religion. Leipzig: Koehler \& Amelang.

Schrage, W 1964. Das Verhältnis des Thomas-Evangeliums zur synoptischen Tradition und zu den koptischen Evangelienübersetzungen, zugleich ein Beitrag zur gnostischen Synoptikerdeutung. Berlin: Töpelmann.

Ward, R B 1969. Partiality in the Assembly: James 2:2-4. HRT 62, 87-97. 